\title{
HOSPITALINIO MIRŠTAMUMO NUO INFEKCINIO ENDOKARDITO PRIEŽASTINIAI VEIKSNIAI
}

\author{
Mindaugas Malinauskas ${ }^{1}$, Diana Žaliaduonyte் ${ }^{1}$, Andrius Minelga ${ }^{1}$, \\ Reda Aržanauskiené ${ }^{1}$, Vytautas Zabiela ${ }^{1,2}$ \\ ${ }^{1}$ Lietuvos sveikatos mokslu universiteto Kardiologijos klinika, \\ ${ }^{2}$ Lietuvos sveikatos moksly universiteto Kardiologijos institutas
}

Raktažodžiai: infekcinis endokarditas, epidemiologija, hospitalinis mirštamumas, daugiaveiksnè logistinès regresijos analizè.

\section{Santrauka}

Aktualumas. Infekcinis endokarditas (toliau - IE) yra klastinga, širdies vožtuvus pažeidžianti infekcinè liga, dažnai sukelianti organų funkcijos nepakankamumą. Nepaisant naujų diagnostikos ir gydymo metodų taikymo, sergančiųjų šia liga mirštamumo rodikliai nemažèja. Kinta jos manifestavimo formos, eigos ypatumai, sukèlejo reikšmè, todèl aktuali šios ligos hospitalinio mirštamumo priežasčių analizè. Tyrimo tikslas. Išanalizuoti Lietuvos sveikatos mokslų universiteto (toliau - LSMU) ligoninès Kauno klinikų Kardiologijos skyriaus 2014-2017 m. hospitalinio mirštamumo nuo infekcinio endokardito priežastinius veiksnius.

Tiriamieji ir tyrimo metodai. Atliktas retrospektyvinis tyrimas. Tiriamujų grupę sudare LSMU ligoninès Kauno klinikų Kardiologijos skyriaus pacientai $(\mathrm{N}=135)$ : 78 vyrai $(57,8$ proc.) ir 57 moterys $(42,2$ proc.), 2014-2017 m. gydyti dèl IE. Surinkti duomenys apie IE formas, eigos ypatumus, komplikacijas, sukèlejjus. Statistinè analizè atlikta naudojant SPSS 19.0 programos paketą. Tyrimo pradžioje lygintas kintamųų (lyties, amžiaus, IE formų, sukèlëjų, komplikacijų) pasiskirstymas tarp mirusių ligoninèje nuo IE ir išgyvenusių pacientų, vẻliau atlikta daugiaveiksnè logistinès regresijos analizè, siekiant ivertinti nepriklausomus priežastinius hospitalinio mirštamumo nuo IE veiksnius.

Rezultatai ir apibendrinimas. Pirminiu IE sirgo 45 ligoniai (33,3 proc.), antriniu - 90 (66,7 proc.). Protezuoto vožtuvo IE nustatytas 40 ligonių (30,3 proc.), $92(69,7$ proc.) IE pažeidè natyvinius vožtuvus. Daž- niausiai (38,5 proc. atvejų) liga manifestavo klasikine forma, 20,0 proc. - širdies nepakankamumu, 8,9 proc. plautine forma, 7,4 proc. atvejų pasireiške sepsis su šoku. IE embolinès komplikacijos nustatytos 25,9 proc., inkstų funkcijos nepakankamumas 55,6 proc., IV funkcinès klasès širdies nepakankamumas pagal Niujorko širdies asociacijos sistemos (toliau NYHA) klasifikaciją 29,6 proc. ligoniu. Tiriamuoju laikotarpiu iš 135 sirgusių IE, 18 (13,3 proc.) mire ligonineje. Tiriamojoje imtyje mirštamumo nuo IE tikimybę patikimai didino protezuoto vožtuvo IE, sepsinè klinikinè IE forma, inkstų funkcijos nepakankamumas, sukèlejjas Staphylococcus epidermidis. Mirties nuo IE tikimybę patikimai mažino atlikta širdies operacija.

\section{Ivadas}

Platus IE diagnostikos ir gydymo metodų taikymas nesumažino šios ligos paplitimo pasaulyje. Nemažèja ir komplikacijų skaičius, lemiantis ankstyvą hospitalinę ligonių mirtị. Apie ketvirtadalis sergančiujų IE miršta ligoninejje, o mirtingumas nuo šios ligos per pastaruosius penkerius metus siekia 45 procentus $[1,2]$. Daugelio studijų analizè parodé, kad dažniausios priežastys, dèl kurių sergantieji IE miršta ligoninëje, buvo ligonio charakteristikos (senyvas amžius, cukrinis diabetas, imunosupresija, inkstų ar plaučių ligos), kardialinès ir kitos komplikacijos (širdies, inkstų nepakankamummas, sepsinis šokas, kraujavimas ị smegenis, platesnis išeminis insultas), infekcijos sukèlèjas Stafilococcus aureus [3, 4].

Lietuvoje atlikto tyrimo duomenimis, 1999-2001 m. LSMU ligoninès Kauno klinikų Kardiologijos skyriuje IE nustatytas 138 ligoniams, hospitalinis mirštamumas 25,2 proc., o jo rizikos veiksniai buvo stafilokokinè infekcija, neurologinès ir inkstų komplikacijos bei IV funkcinès klasès širdies nepakankamumas pagal NYHA [5]. Vilniaus universitete atliktame tyrime $(\mathrm{N}=101)$ tiriamujų grupę sudarè 
IE sirgę pacientai, 2007-2009 metais operuoti Vilniaus universitetinès ligoninès Santariškių klinikose [6]. Hospitalinis mirštamumas nuo IE sudare 14,9 proc., mirštamumą didinę veiksniai buvo: amžius $>60$ metų, NYHA IV funkcinès klasès širdies nepakankamumas, dviejų širdies vožtuvų protezavimo operacija.

Tyrimo tikslas - nustatyti LSMU ligoninès Kauno klinikų Kardiologijos skyriuje nuo IE 2014-2017 m. gydytų ligonių hospitalinio mirštamumo priežastinius veiksnius.

\section{Tyrimo objektas ir metodai}

Atliktas retrospektyvinis tyrimas. Tiriamujų grupę sudarè LSMU ligoninès Kauno klinikų Kardiologijos skyriuje 2014$2017 \mathrm{~m}$. nuo IE gydyti ligoniai $(\mathrm{N}=135)$ : 78 vyrai $(57,8$ proc.) ir 57 moterys (42,2 proc.). Gavus Bioetikos centro leidimą, išnagrinetos sirgusiujų IE ligos istorijos. Vidutinis ligonių amžius buvo $62,36 \pm 15,02$ metų. 73 (54, 1 proc.) iš jų buvo Kauno apskrities gyventojai, 46 (34,1 proc.) Kauno miesto (rajono) gyventojai, kiti atsiųsti ị LSMU Kauno klinikas iš ịvairių Lietuvos gydymo ịstaigų. IE diagnozuotas remiantis modifikuotais Duke kriterijais [7]. IE nustatytas 97 (71,9 proc.), galimas - 38 ligoniams ( 28,1 proc.).

Pirminiu IE sirgo 45 (33,3 proc.), antriniu - 90 ligonių (66,7 proc.). Protezuoto vožtuvo IE nustatytas 40 ligonių (30,3 proc.); 92 (69,7 proc.) ligoniams IE pažeidè natyvinius vožtuvus. 3 ligonių infekcinis procesas pažeide tik elektrokardiostimuliatoriaus laidus, vieno - elektrokardiostimuliatoriaus laidus ir 2 vožtuvus. Pirmas IE epizodas diagnozuotas 105 (77,8 proc.), pakartotinis IE - 30 (22,2 proc.) ligonių.

Ankstyvą IE diagnostiką sunkina kintanti IE simptomatika ir klinikinis ligos pasireiškimas. Sirgusieji IE buvo suskirstyti i grupes pagal klinikinès formos pasireiškimą [8, 9]. Greta tipiškos (hektinis karščiavimas su šaltkrecčiu), nustatytos netipiškos IE klinikinès formos (širdies nepakankamumo, embolinè, plautinè, meningoencefalitinè, inkstinè, sepsinè (sepsis ir kraujospūdžio mažejimas), reumatinè, akių, aneminè, trombocitopeninè, elektrokardiostimuliatoriaus).

Statistinè analizè atlikta naudojant SPSS 19.0 programos paketą. Analizèje pateikti absoliutūs skaičiai $(\mathrm{N})$ ir jų procentinè išraiška (proc.), tolygiujų kintamųjų vidutinès vertès su standartiniu nuokrypiu (SD). Kategorinių kintamujų palyginimui taikytas chi kvadrato $\left(\chi^{2}\right)$ kriterijus, vidurkiai buvo lyginami taikant Student $(\mathrm{t})$ testą. Rezultatai buvo laikomi statistiškai reikšmingais, kai paklaidos tikimybès reikšmė buvo $\mathrm{p}<0,05$, esant 95 proc. pasikliautino intervalo patikimumui. Pradžioje lygintas kintamuju (lyties, amžiaus, IE formų sukèlejų, komplikacijų) pasiskirstymas tarp mirusių nuo IE ir išgyvenusių ligonių, vèliau atlikta daugiaveiksnè logistinès regresijos analizè, siekiant ịvertinti nepriklausomus IE mirštamumo priežastinius veiksnius.

\section{Rezultatai}

Mūsų tyrimas atskleidè, kad suagusiųjų sergamumas IE 2014-2017 metais Kauno apskrityje buvo 3,22/100 000 gyventojų per metus, o Kauno mieste - 3,96/100 000 gyventojų per metus. Ligonių pasiskirstymas pagal IE manifestavimo klinikines formas pateiktas 1 lentelèje. Dažniausiai liga manifestavo klasikine forma (38,5 proc. atvejų), 20,0 proc. atvejų - širdies nepakankamumu, 8,9 proc. atvejų - plautine forma (infarktpneumonija ir absceduojanti pneumonija), 7,4 proc. atvejų pasireiškè sepsiu su šoku. IE embolinès komplikacijos nustatytos 25,9 proc. ligonių, inkstų funkcijos nepakankamumas 55,6 proc., NYHA IV funkcinè klasė 29,6 procentų. Ligos sukèlejas Staphylococcus aureus, nustatytas 29 ligoniams (23,0 proc.), lèmė 29,4 proc. natyvinio vožtuvo IE atvejų. IE sepsine forma manifestavo 10 ligonių: 7 kraujo pasèliuose išaugintas Staphylococcus aureus, iš jų 4 mirè. Kitiems Staphylococcus aureus lèmè klasikinę (10 atvejų), meningoencefalitinę ( 5 atvejai), plautinę ( 3 atvejai) IE formas. Iš viso nuo Staphylococcus aureus sukelto IE mirè 6 ligoniai. Staphylococcus epidermidis sukèlè 5,2 proc. visų IE atvejų (klasikinès formos IE - 4 atvejus, širdies nepakankamumo formos IE - 2 atvejus ir plautinès formos IE - 1 atveji), bet lèmé 15,0 proc. visų protezuoto vožtuvo IE atvejų ir 16,7 proc. mirčių nuo IE.

Tiriamuoju laikotarpiu iš 135 IE sirgusių ligonių $18(13,3$ proc.) mirè ligoninejje. 1 lenteleje pateiktas tirtų kintamujų pasiskirstymas ligonineje mirusių ir išgyvenusių pacientų grupèse. Grupès nesiskyrè pagal demografinius rodiklius, IE formas, tačiau patikimai daugiau mire ligonių, kuriems IE manifestavo sepsine forma, glomerulonefritu, inkstų funkcijos nepakankamumu, kepenų pažeidimu, NYHA IV funkcine klase ir iš kraujo buvo išaugintas sukèlèjas Staphylococcus epidermidis. Daugiaveiksnès logistinès regresijos analizès modelyje statistiškai patikimai išsiskyrẻ šie nepriklausomi priežastiniai mirties nuo IE veiksniai: protezuotas vožtuvas IE (GS=5,21; 96 proc. PI 1,15-23,5), sepsis su šoku (GS=9,64; 95 proc. PI 2,16-43,0), inkstų funkcijos nepakankamumas (GS=6,01; 95 proc. PI 1,13-31,99), Staphylococcus epidermidis (GS=8,18; 95 proc. PI 1,02-65,4). Hospitalinio mirštamumo tikimybę patikimai mažino atlikta šrdies operacija (GS=0,191; 95 proc. PI 0,042-0,868).

\section{Rezultatų aptarimas}

IE yra klastinga liga, kuri gali prasidèti staigiu karščiavimu su šaltkrèčiu ar progresuojančiu širdies nepakankamumu, arba vangiai, nesant ryškesnės IE būdingos klinikos ir neretai baigtis mirtimi. Šiame straipsnyje pateikiama 20142017 metais LSMU Kauno klinikų Kardiologijos klinikoje nuo IE gydytų ligonių mirties priežastinių veiksnių analizè. Tiriamuoju laikotarpiu iš 135 sirgusiujų IE, 18 (13,3 proc.) 
1 lentelè. Mirusiųų nuo IE ir išgyvenusiųjų ligonių klinikinių būklių pasisikirstymas, vienmatės ir daugiaveiksnès statistinès analizès rezultatai

GS*- galimybiu santykis, 95 proc. PI - 95 proc. pasikliautinieji intervalai; LŠN vystymosi stadijos**: (NYHA**:Amerikos kardiologu kolegijos ir Amerikos širdies asociacijos širdies nepakankamumo ịvertinimo ir gydymo 2001 m. gairès)

\begin{tabular}{|c|c|c|c|c|c|c|c|}
\hline \multirow{3}{*}{ Analizuoti kintamieji } & \multirow{3}{*}{$\begin{array}{c}\text { Visi } \\
\mathbf{N}=135 \\
\mathrm{~N}, \text { (proc.) }\end{array}$} & \multirow{3}{*}{\begin{tabular}{|c|} 
Mirusieji \\
$\mathbf{N}=\mathbf{1 8}$ \\
$\mathrm{N}$, (proc.)
\end{tabular}} & \multirow{3}{*}{\begin{tabular}{|c|} 
Išgyvenę \\
$\mathbf{N}=117$ \\
$\mathrm{~N}$, (proc.) \\
\end{tabular}} & \multicolumn{4}{|c|}{ Statistinè analizè } \\
\hline & & & & \multirow{2}{*}{$\begin{array}{l}\text { Vienmatè } \\
\text { p reikšmè }\end{array}$} & \multicolumn{3}{|c|}{$\begin{array}{c}\text { Daugiaveiksnė logistinė } \\
\text { regresija }\end{array}$} \\
\hline & & & & & p reikšmé & GS* & 95 proc. $\mathrm{PI}$ \\
\hline $\begin{array}{l}\text { Amžiaus vidurkis (metais) } \\
\text { Standartinis nuokrypis }( \pm)\end{array}$ & $\begin{array}{c}62,36 \\
( \pm 15,02)\end{array}$ & $\begin{array}{c}67,78 \\
( \pm 7,70)\end{array}$ & $\begin{array}{c}61,52 \\
( \pm 15,70)\end{array}$ & 0,100 & & & \\
\hline $\begin{aligned} \text { Lytis: } & \text { Vyrai } \\
& \text { Moterys }\end{aligned}$ & $\begin{array}{l}78(57,8) \\
57(42,2)\end{array}$ & $\begin{array}{l}10(55,6) \\
8(44,4)\end{array}$ & $\begin{array}{l}68(58,1) \\
49(41,9)\end{array}$ & 0,838 & & & \\
\hline $\begin{array}{c}\text { Gyvena: mieste } \\
\text { kaime }\end{array}$ & $\begin{array}{l}90(66,7) \\
45(33,3)\end{array}$ & $\begin{array}{c}11(61,1) \\
7(38,9)\end{array}$ & $\begin{array}{l}79(67,5) \\
38(32,5)\end{array}$ & 0,591 & & & \\
\hline $\begin{array}{l}\text { Pirminis IE } \\
\text { Antrinis IE }\end{array}$ & $\begin{array}{l}45(33,3) \\
90(66,7)\end{array}$ & $\begin{array}{c}7(38,9) \\
11(61,1)\end{array}$ & $\begin{array}{l}38(32,5) \\
79(67,5)\end{array}$ & 0,591 & & & \\
\hline $\begin{array}{l}\text { Protezuoto vožtuvo IE } \\
\text { Natyvinio vožtuvo IE }\end{array}$ & $\begin{array}{l}40(29,6) \\
95(70,4)\end{array}$ & $\begin{array}{c}8(44,4) \\
10(55,6)\end{array}$ & $\begin{array}{l}32(27,4) \\
85(72,6)\end{array}$ & 0,139 & 0,032 & 5,21 & $1,15-23,5$ \\
\hline $\begin{array}{l}\text { Pirmas IE epizodas } \\
\text { Pakartotinis IE }\end{array}$ & $\begin{array}{c}105(77,8) \\
30(22,2)\end{array}$ & $\begin{array}{c}12(66,7) \\
6(33,3) \\
\end{array}$ & $\begin{array}{l}93(79,5) \\
24(20,5)\end{array}$ & 0,223 & & & \\
\hline $\begin{array}{l}\text { IE klinikinès formos: } \\
\text { Klasikinė } \\
\text { Širdies nepakankamumo } \\
\text { Plautinė } \\
\text { Embolinė } \\
\text { Sepsinė } \\
\text { Reumatinè (sąnarių) } \\
\text { Meningoencefalitinė } \\
\text { Inkstinè } \\
\text { EK Stimuliatoriaus } \\
\text { Kitos }\end{array}$ & $\begin{array}{c}52(38,5) \\
27(20,0) \\
12(8,9) \\
10(7,4) \\
10(7,4) \\
4(3,0) \\
5(3,7) \\
5(3,7) \\
4(3,0) \\
6(4,4)\end{array}$ & $\begin{array}{c}7(38,8) \\
2(11,1) \\
- \\
- \\
6(33,3) \\
- \\
1(5,6) \\
1(5,6) \\
- \\
1(5,6) \\
\end{array}$ & $\begin{array}{c}45(38,5) \\
25(21,4) \\
12(10,3) \\
10(8,5) \\
4(3,4) \\
4(3,4) \\
4(3,4) \\
4(3,4) \\
4(3,4) \\
5(4,3) \\
\end{array}$ & 0,003 & 0,003 & 9,64 & $2,16-43,0$ \\
\hline $\begin{array}{l}\text { IE embolinės komplikacijos } \\
\text { Smegenų arterijų embolijos } \\
\text { Plaučių arterijos embolija } \\
\text { Blužnies arterijos embolija } \\
\text { Embolinis miokardo infarktas } \\
\text { Galūnių embolija } \\
\text { Poliembolinė forma }\end{array}$ & $\begin{array}{c}35(25,9) \\
18(13,3) \\
4(3,0) \\
5(3,7) \\
3(2,2) \\
9(6,7) \\
12(8,9) \\
\end{array}$ & $\begin{array}{c}5(27,8) \\
3(16,7) \\
1(5,6) \\
1(5,6) \\
1(5,6) \\
1(5,6) \\
3(16,7) \\
\end{array}$ & $\begin{array}{c}30(25,6) \\
15(12,8) \\
3(2,6) \\
4(3,4) \\
2(1,7) \\
8(6,8) \\
9(7,7) \\
\end{array}$ & $\begin{array}{l}0,847 \\
0,655 \\
0,486 \\
0,655 \\
0,303 \\
0,839 \\
0,213 \\
\end{array}$ & 0,155 & 3,43 & $0,63-18,7$ \\
\hline Inkstų funkcijos nepakankamumas & $75(55,6)$ & $14(77,8)$ & $61(52,1)$ & 0,042 & 0,035 & 6,01 & $1,13-31,99$ \\
\hline Glomerulonefritas & $52(38,5)$ & $11(61,1)$ & $41(35,0)$ & 0,034 & 0,149 & 2,86 & $0,69-11,95$ \\
\hline Kepenų pažeidimas & $45(33,3)$ & $10(55,6)$ & $35(29,9)$ & 0,032 & 0,268 & 2,18 & $0,55-8,65$ \\
\hline $\begin{array}{l}\text { Lėtinis širdies nepakankamumas**: } \\
\text { NYHA } 1 \text { funkcinè klasė } \\
\text { NYHA } 2 \text { funkcinè klasė } \\
\text { NYHA } 3 \text { funkcinè klasė } \\
\text { NYHA } 4 \text { funkcinè klasė }\end{array}$ & $\begin{array}{l}12(8,9) \\
35(25,9) \\
48(35,6) \\
40(29,6)\end{array}$ & $\begin{array}{l}4(22,2) \\
2(11,1) \\
4(22,2) \\
8(44,4)\end{array}$ & $\begin{array}{c}8(6,8) \\
33(28,2) \\
44(37,6) \\
32(27,4)\end{array}$ & 0,037 & 0,283 & 3,81 & $0,56-25,99$ \\
\hline $\begin{array}{r}\text { IE chirurgija: operuoti } \\
\text { neoperuoti } \\
\end{array}$ & $\begin{array}{l}79(58,5) \\
56(41,5) \\
\end{array}$ & $\begin{array}{l}7(38,9) \\
11(61,1) \\
\end{array}$ & $\begin{array}{l}72(61,5) \\
45(38,5) \\
\end{array}$ & 0,069 & 0,032 & 0,191 & $\begin{array}{c}0,042- \\
0,868\end{array}$ \\
\hline $\begin{array}{l}\text { Sukèlejas: Stafilokokas } \\
\quad \text { Streptokokas } \\
\text { Staphylococcus aureus } \\
\text { Staphylococcus epidermidis } \\
\text { Enterokokas }\end{array}$ & $\begin{array}{c}43(31,9) \\
15(11,1) \\
31(23,0) \\
7(5,2) \\
5(3,7)\end{array}$ & $\begin{array}{c}9(50,0) \\
2(11,1) \\
6(33,3) \\
3(16,7) \\
1(5,6)\end{array}$ & $\begin{array}{c}34(29,1) \\
13(11,1) \\
25(21,4) \\
4(3,4) \\
4(3,4)\end{array}$ & $\begin{array}{c}0,076 \\
1,0 \\
0,261 \\
0,018 \\
0,655\end{array}$ & $\begin{array}{l}0,312 \\
0,048\end{array}$ & 8,18 & $1,02-65,4$ \\
\hline
\end{tabular}


mire ligoninejje. Šis mirštamumo rodiklis nèra aukštas, nes 2015 m. Europos kardiologų asociacijos pateiktame dokumente nurodoma, kad sergančiųų IE hospitalinis mirštamumas varijuoja nuo 15 iki 30 proc. [3], o 1999-2001 m. LSMU Kauno klinikų Kardiologijos klinikoje atliktame analogiškame tyrime hospitalinis mirštamumas nuo IE sudare 25,2 procentus [5]. Suomijos mokslininkų grupè nustaté, kad 11,3 proc. sirgusių IE mire per pirmąsias 30 hospitalizacijos dienų [10].

Mes tyrème hospitalinio mirštamumo nuo IE priežastinius veiksnius, taikydami daugiaveiksnès logistinès regresijos analizès modeli ir nustatėme, kad tiriamojoje imtyje mirštamumo nuo IE tikimybę patikimai didino protezuoto vožtuvo IE, sepsinè klinikinè IE forma, inkstų funkcijos nepakankamumas, sukèlejjas Staphylococcus epidermidis, o mirties nuo IE tikimybę patikimai mažino atlikta širdies operacija. Kiti autoriai nurodo, kad ligoniams, anksčiau sirgusiems IE, didesnè reinfekcijos rizika. Reinfekcija dažnesnè intraveninių narkotikų vartotojų, ligonių su protezuotais vožtuvais grupése. Reinfekcijos atvejais yra didesné vožtuvo keitimo operacijos tikimybè ir mirties rizika [11]. Mūsų tiriamoje imtyje buvo tik vienas intraveninių narkotikų vartojimo sukeltas triburio vožtuvo IE. Protezuotų vožtuvų IE pasižymi sunkia ligos eiga, dažniau su paravalvuliniu išplitimu ir nustatytu stafilokoko mikroorganizmu kraujo pasėlyje. Didelis IE mirštamumas nustatomas dèl pakenkto aortos protezuoto vožtuvo IE atveju, sunkių komplikacijų, tokių kaip abscesas, komplikuotas išeminis insultas ir kraujavimas ị smegenis [12]. Literatūros šaltinių duomenimis, inkstų nepakankamumas yra dažna IE komplikacija (6-30 proc. atvejų), lemianti didesnị hospitalinį mirštamumą. Inkstų nepakankamumą gali sukelti imuniniai kompleksai, vaskulitas, glomerulonefritas, inkstų infarktas dèl sepsinio embolo, hemodinamikos sutrikimai sergant širdies nepakankamumu ar sunkiu sepsiu, po širdies operacijos, antibiotikų toksiškumas (intersticinis nefritas), kontrastinių medžiagų naudojimas radiologiniais tikslais $[3,13,14]$. Dauguma autorių nurodo, kad sepsinis šokas yra blogą ligos prognozę lemiantis veiksnys [3] ir kad Staphylococcus aureus infekcija, siejama su sepsiniu šoku, lemia prastą klinikinę eigą, išliekančią infekciją ir aukštą mirtingumą IE atvejais [15,16]. Sepsinis šokas, dažnai nulemtas Staphylococcus aureus bakteremijos, sukelia neurologines komplikacijas, embolizacijas ir blogą ligos baigti [17]. Mūsų tyrimo duomenimis, 4 ligoniai mirè dèl Staphylococcus aureus sukelto sepsio, tačiau dauguma Staphylococcus aureus sukeltą IE išgyveno (mirè 6 iš 29), todèl daugiaveiksnès logistinès regresijos analizès modelyje Staphylococcus aureus neišryškejjo kaip nepriklausomas hospitalini mirštamumą lemiantis veiksnys. Kiti autoriai nurodo, kad stafilokokinis IE buvo susijęs su naujai atsira- dusiu širdies nepakankamumu, bet nebuvo nepriklausomas mirties veiksnys [18].

Apie Staphylococcus epidermidis reikšmę IE etiologijoje plačiai diskutuota ankstesnèse studijose, nurodant, kad šis, ant odos randamas sukèlejjas, patekęs ị organizmą intervencinių procedūrų metu, dažnai sukelia protezuotų širdies vožtuvų vangios eigos IE [19]. Ankstesnès studijos charakterizavo Staphylococcus epidermidis protezuoto vožtuvo IE kaip gana vangios eigos ligą, kuri paveikia vožtuvo siuvimo žiedą, galimai dèl bakterijos patekimo ị žiedo aplinką nuo odos ar chirurginès operacijos metu. Kitos studijos parodè Staphylococcus epidermidis sukelto natyvinio vožtuvo IE agresyvią eigą, lemiančią vožtuvo destrukciją, širdies nepakankamumą ir mirtị [20]. Ir kitų autorių nuomone, Staphylococcus epidermidis sukeltas natyvinio vožtuvo IE siejamas su bloga ligos baigtimi [19].

Mūsų tyrimo duomenimis, stacionarizavimo metu atlikta širdies operacija mažino hospitalinio mirštamumo tikimybę. Kiti autoriai nurodo, kad sunku ịvertinti tinkamą laiką bei naudą širdies operacijai IE atvejais. Ankstyva operacija pagerina prognozę, ypač natyvinio vožtuvo IE atvejais, tada sumažèja embolizacijos rizika (21). Kai kurie autoriai nurodo, kad hospitalinį mirštamumą nuo IE lemia širdies nepakankamumas (20,8 proc.), neurologinès komplikacijos (16,7proc.) [16], smegenų embolai, NYHA III/IV klasės širdies nepakankamumas [22]. Kiti nurodo, kad dauguma sergančiujų IE turi preegzistuojančią širdies ligą, tad širdies nepakankamumas gali pasunkinti sisteminę cirkuliacijos perkrovą ir sukelti nepakankamą inkstų perfuziją. Inkstų ir širdies nepakankamumas IE atvejais sukuria ydingą ratą ir lemia vis blogèjančią ligonių būklę [23]. Gydymo metu atsiradusios komplikacijos, susijusios su didesne mirties tikimybe, buvo širdies nepakankamumas, nauja embolizacija (kita, nei insultas), neurologinès komplikacijos ir nekontroliuojama infekcija [18]. Mūsų tyrimo duomenimis, NYHA IV klasès širdies nepakankamumas siejosi su hospitaliniu mirštamumu nuo IE vienmateje analizejje $(p=0,037)$, tačiau daugiaveiksnès logistinès regresijos analizès modelyje šio kintamojo poveikis buvo statistiškai nereikšmingas. Stebèta embolinių komplikacijų, didinančių IE hospitalinio mirštamumo rodiklius, didèjimo tendencija.

\section{Išvados}

1. 2014-2017 metais LSMU Kauno kliniku Kardiologijos klinikoje nuo IE gydytų ligonių hospitalinis mirštamumas buvo 13,3 procento.

2. Tiriamojoje imtyje mirštamumo nuo IE tikimybę patikimai didino protezuoto vožtuvo IE, sepsinè klinikinè IE forma, inkstų funkcijos nepakankamumas, infekcijos sukèlëjas Staphylococcus epidermidis. 


\section{4}

3. Mirties nuo IE tikimybę patikimai mažino atlikta širdies operacija.

\section{Literatūra}

1. Abdulhak AA, Baddour LM, Erwin PJ, Hoen B, Chu VH, Mensah $\mathrm{GA}$, et al. Global and regional burden of infective endocarditis, 1990-2010: a systematic review of the literature. Global Heart 2014;9(1):131-43.

https://doi.org/10.1016/j.gheart.2014.01.002

2. Moraga P, GBD 2016 causes of death collaborators. Global, regional, and national age-sex specific mortality for 264 causes of death, 1980-2016: a systematic analysis for the global burden of disease study 2016. Lancet 2017;390(10100):1151-210. https://doi.org/10.1016/S0140-6736(17)32152-9

3. Habib G, Lancellotti P, Antunes MJ, Bongiorni MG, Casalta JP, Del Zotti F. 2015 ESC guidelines for the management of infective endocarditis: the task force for the management of infective endocarditis of the European Society of Cardiology (ESC) endorsed by: European Association for Cardio-Thoracic Surgery (EACTS), the European Association of Nuclear Medicine (EANM). European Heart Journal 2015;36(44):3075-128. https://doi.org/10.1093/eurheartj/ehv319

4. Chu VH, Cabell CH, Benjamin Jr DK, Kuniholm EF, Fowler Jr VG, Engemann J, Sexton DJ, Corey GR, Wang A. Early predictors of in-hospital death in infective endocarditis. Circulation 2004;109(14):1745-9.

https://doi.org/10.1161/01.CIR.0000124719.61827.7F

5. Aržanauskienė R. Infekcinis endokarditas: diagnostikos ir gydymo būdo įtaka komplikacijoms ir baigčiai. Daktaro disertacija, Kaunas, 2002.

6. Šerpytis P., Alitoit I., Čypienė R., Semènienè P., Grebelis A. Pacientu, operuotų dèl infekcinio endokardito, ligos etiologiniai, epidemiologiniai, klinikiniai, mikrobiologiniai rodikliai ir ju ịtaka mirštamumui. Sveikatos mokslai, 2011;21(5):98-103.

7. Li JS, Sexton DJ, Mick N, Nettles R, Fowler Jr VG, Ryan T, et al. Proposed modifications to the Duke criteria for the diagnosis of infective endocarditis. Clinical infectious diseases 2000;30(4):633-8.

https://doi.org/10.1086/313753

8. Crawford MH, Durack DT. Clinical presentation of infective endocarditis. Cardiol Clin 2003;21:159-66. https://doi.org/10.1016/S0733-8651(03)00023-7

9. Žaliaduonytė-Pekšienė D., Jonkaitienẻ R., Zabiela P., Aržanauskienė R. Infekcinio endokardito klinikinès formos Kauno medicinos universiteto klinikose 2002-2005 m. Medicina, 2007;43(7):523-528.

https://doi.org/10.3390/medicina43070066

10. Ahtela E, Oksi J, Porela P, Ekström T, Rautava P, Kytö V. Trends in occurrence and 30-day mortality of infective endocarditis in adults: population-based registry study in Finland. BMJ 2019;9(4):e026811.

https://doi.org/10.1136/bmjopen-2018-026811
11. Alagna L, Park LP, Nicholson BP, Keiger AJ, Strahilevitz J, Morris A, et al. Repeat endocarditis: analysis of risk factors based on the international collaboration on endocarditis - prospective cohort study. Clin Microbiol Infect 2014;20:566-575. https://doi.org/10.1111/1469-0691.12395

12. Mistiaen WP. What are the main predictors of in-hospital mortality in patients with infective endocarditis: a review. Scandinavian Cardiovascular Journal 2018;52(2):58-68.

https://doi.org/10.1080/14017431.2018.1433318

13. Tamura K, Arai H, Yoshizaki T. Long-term outcome of active infective endocarditis with renal insufficiency in cardiac surgery. Annals of Thoracic and Cardiovascular Surgery 2012;18(3):216-21.

https://doi.org/10.5761/atcs.oa.11.01748

14. Miro JM, Ambrosioni J. Infective endocarditis: an ongoing global challenge. European Heart Journal 2019;40(39):3233-6. https://doi.org/10.1093/eurheartj/ehz694

15. Kang CI, Song JH, Chung DR, Peck KR, Ko KS, Yeom JS, et al. Risk factors and pathogenic significance of severe sepsis and septic shock in 2286 patients with gram-negative bacteremia. Journal Infection 2011;62(1):26-33. https://doi.org/10.1016/j.jinf.2010.10.010

16. Lee SJ, Jeon D, Cho WH, Kim YS. The clinical impacts of apparent embolic event and the predictors of in-hospital mortality in patients with infective endocarditis. Journal of Korean Medical Science 2014;29(12):1646-50. https://doi.org/10.3346/jkms.2014.29.12.1646

17. Krajinovic V, Ivancic S, Gezman P, Barsic B. Association between cardiac surgery and mortality among patients with infective endocarditis complicated by sepsis and septic shock. Shock: Injury, Inflammation, and Sepsis: Laboratory and Clinical Approaches 2018;49(5):536-42.

https://doi.org/10.1097/SHK.0000000000001013

18. Nunes MC, Guimarães-Júnior MH, Pinto PH, Coelho RM, Barros TL, Maia ND, et al. Outcomes of infective endocarditis in the current era: early predictors of a poor prognosis. International Journal of Infectious Diseases 2018;68:102-7. https://doi.org/10.1016/j.ijid.2018.01.016

19. Monk AB, Boundy S, Chu VH, Bettinger JC, Robles JR, Fowler $\mathrm{VG}$, Archer GL. Analysis of the genotype and virulence of staphylococcus epidermidis isolates from patients with infective endocarditis. Infection and immunity 2008;76(11):5127-32. https://doi.org/10.1128/IAI.00606-08

20. Chu VH, Woods CW, Miro JM, Hoen B, Cabell CH, Pappas PA, Federspiel J, Athan E, Stryjewski ME, Nacinovich F, Marco F. Emergence of coagulase-negative staphylococci as a cause of native valve endocarditis. Clinical Infectious Diseases 2008;46(2):232-42. https://doi.org/10.1086/524666

21. Ohara T, Nakatani S, Kokubo Y, Yamamoto H, Mitsutake $\mathrm{K}$, Hanai S, CADRE investigators. Clinical predictors of inhospital death and early surgery for infective endocarditis: 
results of Cardiac Disease Registration (CADRE), a nationwide survey in Japan. International Journal of Cardiology 2013;167(6):2688-94.

https://doi.org/10.1016/j.ijcard.2012.06.117

22. Elbey MA, Kalkan ME, Akdag S, Ozbek K, Eren NK, Demirtas S, et al. Predictors of mortality in patients with prosthetic valve infective endocarditis: a nation-wide multicenter study. Cardiology Journal 2013;20(3):323-8.

https://doi.org/10.5603/CJ.2013.0079

23. Liu Y, Zhang H, Liu Y, Han Q, Tang Y, Zhao L, et al. Risk factors and short-term prognosis of preoperative renal insufficiency in infective endocarditis. Journal of Thoracic Disease 2018;10(6):3679.

https://doi.org/10.21037/jtd.2018.06.11

\section{PREDICTORS OF IN-HOSPITAL MORTALITY IN INFECTIVE ENDOCARDITIS \\ M. Malinauskas, D. Žaliaduonytė, A. Minelga, R. Aržanauskienė, V. Zabiela}

Keywords: infective endocarditis, epidemiology, in-hospital mortality, multifactorial logistic regression analysis.

Summary

Infective endocarditis (IE) is a life-threatening disease associated with serious complications, including heart failure, usually because of severe valvular insufficiency, and embolic stroke. Significant changes have been reported in IE epidemiology concerning pathogens and patient's characteristics. The clinical features of IE have significantly changed as well as the role of pathogens. Despite trends toward earlier diagnosis and surgical intervention, in-hospital mortality rates have not improved over the last three decades. Therefore, the analysis of in-hospital mortality factors becomes important. The objective of the present study was to de- termine in-hospital mortality factors among patients with IE in Lithuanian University of Health Sciences Kaunas Clinics Cardiology department in the period 2014-2017.

Methods. Retrospective analysis of IE cases $(\mathrm{N}=135)$ at the Lithuanian University of Health Sciences Kaunas Clinics Cardiology department during the period 2014-2017. 78 males (57.8\% and 57 females $(42.2 \%)$ were investigated. Data collected about IE clinical features, course, complications, pathogens. Package "SPSS 19.0" was used in the statistical analysis. Primary, the distribution of the investigated variables (gender, age, IE forms, pathogens, complications) among dead and survivors was evaluated, compared and tested for statistical significance. Secondly, the multifactorial logistic regression analysis was performed to reveal the significant independent in-hospital mortality related factors.

Results. Primary IE was defined in 45 patients (33.3\%), secondary - 90 patients $(66.7 \%)$ Prosthetic valve IE in 40 patients $(30.3$ $\%$ ), in 92 patients $(69.7 \%$ ) native valves were affected. The classical IE clinical form was prevailing (38.5\%), $20.0 \%$ heart failure form, pulmonary form in $8.9 \%$ of cases, septic shock in 7.4 $\%$ of cases, embolic events were determined in $25.9 \%$ of cases, renal failure in $55.6 \%$, a(NYHA) Functional Class 4 in $29.6 \%$. During the investigated period out of 135 patients with IE 18 (13.3 $\%$ ) died in the hospital. The probability of in-hospital mortality in the investigated sample was increased significantly by prosthetic valve IE, septic shock, renal failure, pathogen Staphylococcus epidermidis. Surgical intervention on affected by IE valves diminished the in-hospital death probability.

Correspondence to: mindaugasmalinauskas1210@gmail.com

Gauta 2019-12-01 